\title{
The role of the South African Online User Group (SAOUG) in the informatisation of society
}

\author{
JC Theron' \\ Department of Information Science, PO Box 392, Unisa 0003, South Africa \\ therojc@unisa.ac.za
}

\begin{abstract}
Received:28 $8^{\text {th }}$ October 2003
Revised: $25^{\text {th }}$ May 2004

The study investigates the concept of 'informatisation', its meaning, history and influence on contemporary society. Informatisation refers inter alia to the widespread use of information in society to survive, to produce food, to manufacture products for local consumption and export, and to render services to society. It is, however, often regarded as a much broader concept, which indicates a new kind of society different from the Industrial or agricultural. In the second part of the study the role that the South African Online User Group (SAOUG) can play in the informatisation of the South African society is investigated and certain recommendations are made.
\end{abstract}

Keywords: Informatisation, Societal informatisation, South African Online User Group. Role of the SAOUG in informatisation of society, South Africa, Unisa

The concept of 'Informatisation of society' may be familiar to many informaticians and information professionals but for some it may be a foreign or unknown concept. This may be partly because the concept is better known in French as l'informatisation and a search using Google on the Internet yielded 21900 results, the majority in French but quite a number in English as well (Google 17 May 2003).

In this paper the concept is explained and the history of the development of the idea briefly discussed. Thereafter some applications of Informatisation are discussed. The aims and functions of online user groups and more specifically those of the South African Online User Group (SAOUG) are discussed. Can these be expanded? In the final instance suggestions are made for the SAOUG to change and, for instance, to become more involved in the process of societal informatisation.

\section{Informatisation of society}

The concept 'informatisation' is closely linked to the importance and presence of information in contemporary society and the notion of the 'information society'. Dick (2002:4) uses informatisation and 'stresses continuity with the past instead of a clean break with it as "information society" talk implies. He further quotes Lacroix \& Tremblay (1997: 127-8 in Dick 2002:78), which states that informatisation is characterised by, among other things,

- a deepening and extension of the dynamic specific to capitalist industrial societies by means of new ICT's Information and computer technologies- my insert, instead of a radical rupture with industrial society;

- a shift nonetheless from one mode of production and consumption to others;

- a growing 'computerisation' of society, which does not really amount to an information society;

- a rejection of technological determinism and a call to conduct meticulous studies that restore the importance of social, economic, legal, cultural and political factors to explain current global changes.

The idea of informatisation therefore is that there are not just, either an information society or other kinds of societies, or that the information society should be seen as the ultimate stage of socioeconomic development and that this is the norm all societies should strive to achieve. Informatisation as a concept recognises that different societies pre-exist, that they develop in different directions and that technology is not the only determining factor. Social, historical and political factors play just as an important role (Dick 2002:79).

Dick (2002:124) also proposes informatisation as a suitable context for the understanding of the regulation of information. The broad scope of the concept, which include amongst others, social, political, technological aspects and so forth, makes it suitable to study the regulation of information in different contexts, in different types of societies and to emphasise the uniqueness of the regulation of the information sector compared to the regulation of manufacturing or agricultural sectors.

I. The late Christie Theron was a Lecturer in the Department of Information Science, University of South Africa. 
In the English-Russian Glossary on Information Society (200I) Informatisation is defined as:

I. Intensification of the production and dissemination of information and knowledge based on ICT usage.

2. Wide-scale usage of ICTs in all spheres of economic, political and cultural life meant to enhance the efficiency of information and knowledge usage in management and gratification of information needs of citizens, organizations and the state.

Other definitions and attempts to describe informatisation as concept includes inter alia De Beer (1996; 1998); Lim (1999); Haywood (1997); Kumon (1999); Levy (1993 as quoted by De Beer 1998:86); Nora \& Minc (1981); Suriya (1998) and Wersig (1990). De Beer (1998:86) describes informatisation as the core of our work ("die hart van ons werk").

The network or networked society is often used as a synonym for informatisation. Castells (1996) is one author who uses it in this context. The networked society relies on the extensive use of computers and telecommunications to function effectively ( $\operatorname{Lim}$ 1999:2). Informatisation is also used by many authors as synonymous with the information society or the knowledge society. It should, however, be emphasised that the information or knowledge society is used here in a broader context as just the economic context as represented by the writings of Machlup and Porat, for instance. Recent contributions by de Beer (2002) and Theron (2003) emphasise the fact that the knowledge society is a multifaceted and new form of society with economic, social, technological, human, informational and knowledge dimensions.

The concept informatisation is used in this article to describe a new kind or type of society different from the agricultural, industrial or modern society, but still related to these societies. These societies were created at, or evolved as a result of the growth in the use of communications technologies such as telecommunication and computer networks. These technologies are used to enhance production technologies to make societies more competitive in global terms, to push societies towards globalisation but also to create new industries such as the information industries, which concern themselves with the creation, production and dissemination of information.

Informatisation also functions on a deeper and more spiritual level in society. In an informatised society knowledge is created, produced and used differently (there is even talk of a new kind of knowledge different from, for example, of those in the industrial society De Beer: 1998). An example of this is the acknowledgement of other forms of knowledge such as indigenous knowledge systems or collective intelligence (Levy 1997). Informatisation influences people in subtle ways. We may adopt a new thinking style, a new worldview or a new way of looking at the world or at literature. De Mul (1999) discussed the informatisation of the worldview at length and referred to it as the informationistic worldview. This differs considerably from Dijksterhuis's concept of a mechanistic worldview (de Mul 1999:74). These changes can perhaps be compared to the influence of the invention of printing and on European society in the 15th century or the development of the natural sciences since Kepler, Copernicus and Newton.

Informatisation as concept also implies a critical look at the production of information, including the regulation thereof, availability of and access to information. Who controls this: governments, the free market economy, or both? Who are the owners of the information? Is the information provided free of charge or must users pay for it? Privacy and ethical issues form an integral part of this process. Last, but not least, is the important question of how power relations, in Foucaultian terms, influence this society and the different discourses in an informatised society.

An informatised society is often portrayed as a kind of Utopia or an earthly paradise but it creates its own sets of problems. Postman 1990 stares that "Technology giveth and technology taketh away, and not always in equal measure. A new technology sometimes creates more than it destroys. Sometimes, it destroys more than it creates."

In this society there are signs of information overload, of people feeling that they cannot cope with all the available information, of trying to locate all information on a topic, etc. Haywood (1997) gives a good description of these phenomena. It should be kept in mind that an informatised society is prone to some unique but also to general societal problems.

The concept informatisation is thus a very broad concept with societal implications. Like all new societies or inventions it has good qualities however, sometimes also unintended, negative influences and characteristics. Any discussion of informatisation therefore has to take cognisance of this and the literature on the topic should be studied with healthy scepticism.

Development of the concept of informatisation

It is now generally accepted that Simon Nora and Alain Minc coined the concept of informatisation in their 1978 publication L'Informatisation de la sociéte which was translated into English in 1980 as The computerization of society. In an article published in 1987 Minc prefers to use the term informatisation and not computerisation but the idea that he wishes to convey remains the same. It is interesting to note that Kumon (1999) claims that the terms informatisation, 
information industry and information society" were originally coined in Japanese. He is supported by Duff (2003) in this regard.

In the above-mentioned report the authors identified the convergence of computers and telecommunications, called "telematique", as a challenge to France to control her own fate (Nora \& Minc 1981:I). Three challenges or consequences were identified, namely,

I. a problem of sovereignty;

2. an economic analysis relating to the productivity gains yielded by such a tool;

3. questions as to the long term development of society" (Minc 1987:134).

After this publication the concept was adopted in French, German and English subject literature and it was broadened to include more aspects than only computers and telecommunications. It is today a concept that forms part of the discourse of the use of information in society, the effects thereof, the social impact of information technologies, globalisation, etc. In a short space of time, 25 years, it has become an important field of study. This, in a sense, confirms the notions underlying the concept of informatisation or the information, or informatised or networked society.

Duff (2003) distinguishes four electronic epochs, he used the term "'e'pochs" to describe the development of the concept of informatisation in specifically the library context. His four "e"pochs include the following:

- Offline use of computers (early 1960s to 1970s)

- Online utilities (early 1970s to early 1980s)

- CD ROM: user-friendly retrieval (mid 1980s to early 1990s)

- The Internet: towards the global library (since early 1990s)

It can be stated, in conclusion, that informatisation as concept owes its existence to the invention, use and convergence of computers and telecommunications in contemporary society. There may be a difference of opinion on whether such a society indeed exists (Lyon 1988) or what it should be called, a post-industrial, an information or a knowledge society. Looking at contemporary society we, however, have to admit that it is a society different from a pre- or post -World War II one. We also have to admit that computers and telecommunications played a key role in transforming society into a different $2 I^{\text {st }}$ century society.

\section{Online user groups}

User groups of especially computer technology and applications of computer technology are established by computer users to share technical advice, give advice on software selection and use, and to learn more about their computers. They can be for a specific kind of computer, for instance Apple, for which more than 600 registered groups exist world wide (Welcome to the Orange Apple Computer Club ... 2004; Seufert 2004).

Online User Groups (OUG's) were established by some of the first online searchers in libraries and other information centres to share knowledge about online searching, to train online searchers, to address specific problems with vendors of such services or with telecommunications providers, etc. They were mostly concerned with the more practical aspects of online searching. Examples of online user groups are the United Kingdom Online User Group (UKOLUG - the UK elnformation group), the Southern Californian Online User Group (SCOUG) and the South African Online User Group (SAOUG).

Changes in technology, the coming of the Internet with its associated web pages and search engines such as Google, e-Books, mobile and wireless communications such as Bluetooth, changed the focus of these online user groups. It is noticeable in the name of UKOLOG - the elnformation Group (italics inserted) and its aim, which is described as 'actively encourages communication and the exchange of knowledge of among users of electronic information resources'. (UKOLOG 2004). Their portfolio includes e-resource management, effective information retrieval strategies, legal compliance, content development, etc. They also fulfil an advocacy role by giving inputs on handling of private information and ethics (UKOLOG 2004).

This trend is also noticed in the latest aims of the SAOUG where it is stated that they provide a forum for the 'applications and opportunities in the expanding field of online information in the broadest sense'. Amongst the group's interests it is noted that it also extends to some of the newest areas of information transfer and exchange (SAOUG 2004).

UKOLOG also regards itself as a professional body for users and developers of electronic information resources. It is a special interest group of the Chartered Institute of Library and Information Professionals (CILIP) and as such can be regarded as a professional society.

In conclusion, it can be stated that it seems as if online user groups have changed from very much a practical oriented grouping concerned with the more technical and narrower aspects of online information searching to professionals much more involved with electronic information sources and their broader social contexts. To what extent the SAOUG has followed the same trend will be investigated in the following paragraphs. 


\section{South African Online Users Group (SAOUG)}

Mission, aims and functions of the SAOUG

In order to determine if the SAOUG can play a role in the informatisation of society their aims and functions should be briefly listed. According to their web site, (http://www.saoug.org.za: 2003) the aims and functions of the SAOUG are as follows:

"The SAOUG provides a forum for the

- exchange of information on current developments

- applications and opportunities in the expanding field of online information in the broadest sense. Our aim is to

- provide an insight into the extent of the growth and activity taking place in the information industry. Our functions include

- uniting online database users in Southern Africa;

- organising meetings, seminars and workshops;

- enabling members to exchange experiences, solve problems and keep abreast of new developments;

- publishing a regular newsletter for ongoing contact;

- being a consumer group, representing its members in dealings with vendors, with database equipment, software suppliers and with Telkom;

- organising and co-coordinating training courses in the use of specific systems and databases."

Activities of the SAOUG

The SAOUG organises bi-annual online user's group conferences, conferences in association with the Special Libraries Interest Group (SLIG) and the Organisation of South African Law Librarians (OSALL). It holds regular meetings and training sessions and address issues pertaining to online information searching.

It is interesting to look at the topics discussed at the conferences and meetings of the SAOUG. Looking at the conference themes from 1997 onwards, the information society, the Internet, digital libraries, disintermediation, current awareness services delivered via the Internet, Information Technology, etc. were addressed in papers, discussions and training sessions. These can be described as examples or attempts at societal informatisation and are indicators that the SAOUG moved away from being an online user group in the strict sense of the term.

The membership of the SAOUG consist of online information searchers employed by private companies or the public sector, librarians, data base vendors and academics such as teachers in Information Science at the Rand Afrikaans University (RAU", the University of Pretoria, and so forth. It can be safely stated that the full spectrum of online information professionals are members of the SAOUG.

From the above it can be deduced that the SAOUG moved their activities, aims and functions from a purely practical interest group for online searchers towards a much more broader approach to include electronic information services such as the Internet, information management, etc. This may not have been done on purpose, it may have been a gradual unnoticed move forced on the SAOUG by the changing needs of its members, changes in technology and society. As indicated earlier, this is in line with the developments at other online user groups such as UKOLOG.

From its aim, functions and activities it can be concluded that the SAOUG can play and indeed plays a role as a specialised interest or pressure group in society catering for the needs of its members, the online user group community in South Africa. The SAOUG also serves the wider interests of other forms of electronic information resources and services through its training courses, meetings and seminars.

A bigger societal role?

From the above it seems as if the question can be put to the SAOUG if it can perhaps play a bigger role in society, especially in a society where access to information is far more of a privilege than a right and where the majority of people are still stuck in an agricultural or preindustrial society while the rest of the world start talking of a post-information society.

This question will be addressed in the next section of the article and the emphasis will be on the role that the SAOUG can play in the informatisation of society. The role that other related organisations such as LIASA can play is not discussed, purely due to space limitations but is important and should be addressed separately. At the same time some proposals may seem irrelevant or audacious, but it forms an essential part of this article to stimulate thinking within SAOUG, to let the society and its members think more theoretical and to force them to reconsider the aims, functions and activities of the SAOUG. Should the SAOUG not be repositioned as a professional society and as an interest group for electronic resources covering aspects such as their creation, regulation, access to and preservation? Should the SAOUG not be on the forefront of the move towards a new informatised society, a society without digital divides and access to information for all and not a privileged few? 


\section{Role of the South African Online User Group in the informatisation of society}

To discuss the role of the SAOUG in the informatisation of the South African society, the part played by the Society itself is discussed first. In the second instance the contribution that individual members of SAOUG can make is pointed out.

Possible role of the SAOUG as a society

The contribution of the SAOUG as a society towards the informatisation of society is discussed under the following headings:

a) Rethinking of aims of the SAOUG

As discussed earlier the SAOUG should seriously consider to broaden its aims and functions to become more of a technical pressure group for online searchers to a society aimed at electronic publication, access to electronic resources, etc. This does not imply that they abandon their traditional role. Consultations with vendors, with TELKOM, the sharing of online searching knowledge and training and so forth will, remain an integral part of their activities. The SAOUG can, for instance, join forces with LIASA, the Online Publishers group, the Association of Southern African Indexers and Bibliographers and the South African Society of Archivists to create a more orderly environment in which electronic records are published and used.

The SAOUG should perhaps change its aims to provide a forum for "applications and opportunities in the expanding field of electronic resources and information in its broadest sense."

Functions to be added can be to act as coordinator and information source on all aspects of electronic information resources and services.

\section{a) Human resource development}

An important part of the informatisation of society is human resource development. Lim (1999) discussed this in his article at length. According to him the OECD (Organisation for Economic Cooperation and Development) distinguishes between four occupational categories in the information industry. These are:

- information producers that create new knowledge, produce information products and services and undertake R\&D (Research and Development). These occupations add value to the production process. Examples of occupations in this category include database producers, writers, consultants, etc.

- information processors can be subdivided into two subcategories, namely, those involved in number crunching using computers and telecommunication networks and those involved in the complex processing of knowledge. These occupations include administrators, managers, process control supervisors, clerical staff,

- information distributors include those involved in knowledge transfer such as educators and teachers, librarians, journalists, advertising executives and actors.

- information infrastructure providers include persons involved in the IT and telecommunications industries such as electronic engineers, programmers and software developers.

These different occupational categories are essential and vital to develop an informatised society and a clear strategy needs to be designed to develop all these occupational categories. Universities and other tertiary educational institutions can provide useful educational opportunities for all four occupational categories.

In this article special attention will be paid to the information distributors. Universities can provide education in information literacy, information tasks such as information and knowledge management or information organisation and retrieval and management of information agencies. It should, however, be acknowledged that universities can reach only a limited percentage of the population as a result of limited resources or as a result of their location in urban centers. How can the rural areas or people not so fortunate to be able to attend universities, be reached?

To achieve this the answer seems to be in the use of societies such as the SAOUG or the Library and Information Association of South Africa (LIASA). How can this be achieved?

The SAOUG can get involved in information literacy training of the users of their libraries and information centres. Users should be made aware of their information needs, how to search for information, how to retrieve it, how to evaluate and use it, etc. The emphasis should be on computer and network literacy although print and visual literacies should not be neglected. Traditional print literacy remains essential to function as a person or as an information distributor in an informatised world. Computer and network literacies do not replace traditional literacy since in the history of human communication it seldom happened that a new form of communication completely replaced an existing one. The ideal should be to educate literate people in the broadest use of the term, not only people who can read and write (Key concepts in communication 1994: 170-171).

Special attention should be paid to the staff of the information agencies, especially those without formal qualifications as information distributors. They should receive training in information literacy as well but can also be trained as trainers 
who can conduct community training after hours or as part of a company's social responsibility programme or a university's community service programmes.

Various teaching methods can be used such as seminars, workshops, in service training and conferences organised by the SAOUG, the information agency itself and other educational providers such as the SETAs (Sectoral Educational and Training Authorities). It is important that the training programmes should be kept in line with the needs of the trainees. As possible future trainers themselves trainees should also be taught the necessary training skills.

\section{b) Awareness programmes}

The SAOUG is in a favourable position to make society aware of the important role that information can play in their daily lives, for instance, to improve their employment prospects or to improve their work performance. Information can be used to improve the productivity of a small manufacturing plant or a farm and to market their products better.

For the SAOUG to become involved in this they could attend events such as the Tourist Indaba or the NAMPO harvest day ("oesdag") and trade shows, especially those aimed at small businesses such as the annual franchise convention. Regular columns in newspapers, especially community newspapers such as Rekord in Pretoria, on new information products and services, contributions on community radio, pamphlets and brochures and the web site of the society itself can also be used. The SAOUG as a society should use every possible opportunity to raise awareness about the central role that information plays in contemporary society. As a by -product the SAOUG can market themselves and become known as an information source on information, especially online and other electronic information.

c) Raise awareness amongst people about their need for information

It is well known that people are often unaware of their need for information simply because they are ignorant about its existence. This especially a problem in Africa (Yumba 2002). This role of the SAOUG is related to (b) above but merit special attention in the article. The SAOUG can fulfill an important role to help people to determine or discover their information needs and how to fulfill these needs by using information resources such as the Internet or other online sources.

As is the case with human resource development the users of the information agency and staff members would be the primary target group although nothing prevents the SAOUG to reach out to communities and individual members in a community to make them aware of their information needs.

\section{d) Taking information services to people}

The SAOUG can, as a society, become involved in projects such as the Multi Purpose Community Centres (MPCCs) established by the Government Communication and Information Service (GCIS) and Telkom. This can be in the form of databases designed to meet the needs of rural people such as information for survival ("bestaansinligting"), small business information, educational and job opportunities, etc. Assistance and advice can be given to the GCIS by the Society since they are experts in online information provisioning.

\section{e) Promotion of the Promotion of Access to Information Act (PAISA)}

This Act is one of the most progressive acts passed by Government and it provides ordinary citizens with the opportunity to gain access to the information held about them by private organisations and the government. As a group of people committed to access to, and the free flow of, information, the SAOUG should be at the forefront of spreading awareness of the Act amongst the users and staff of their institutions but also in society as a whole. The proverbial man in the street should be made aware of his rights under this Act and also those contained in the Bill of Rights.

The Archival profession is setting an example for the SAOUG, especially Verne Harris from the South African History Archives at Wits. This organisation gained access to TRC files after government and its agencies tried to prevent this. The SAOUG should become "activists" for access to, and the free flow of, information.

\section{f)Protection of privacy}

Modern information technologies made the surveillance of persons by Government and private companies much easier than ever before in the history of humankind. This is one of the less desirable consequences of informatisation that information distributors should be aware of (Robins \& Webster 1999). A recent remark made by Minister Buthelezi in Parliament to the effect that he was requested to track the overseas travels of South African citizens, is a good example to what extent Governments are prepared to keep tabs on their citizens. Recent debates in the USA on the role of the National Security Agency and revelations by the BBC on how the government keep their citizens under surveillance are other examples (Extent of UK snooping revealed :2003). Government did this to keep control over its citizens for various and often not so good reasons. Businesses use all kinds of surveillance techniques to gather marketing information, to 
watch their competitors or even directors, for example the recent Kebble case and events at Durban Roodepoort Deep where accusations of undue surveillance were made (Kebbles se dagvaardings na DRD en andere gestuur 2003:6).

The SAOUG could make society aware of their rights to privacy, should campaign for the protection of privacy and publicise the misuse of privileged information. This requires also an "activist" role for the Society but it is incumbent upon the SAOUG to fulfil this function.

\section{g) Guardians of public information}

One of the less desirable outcomes of Thatcherism was that information and knowledge created with taxpayers' money and available for free were privatised. To gain access to that information a fee must now be paid. A local example is the South African Weather Services, formerly, the Weather Bureau, which, although they still provide some services for free, now sell information which they gathered and still gather using tax payers' money. The SAOUG could play an active role to prevent this from happening to other sources of public information through advocacy and making society aware that the Government is selling their property.

In conclusion it seems that the SAOUG as a professional society can contribute to the informatisation of the South African society. To achieve this they should seriously consider the broadening of their aims and functions to include the whole spectrum of electronic resources and information. This should not be done to the detriment of their existing functions such as liaison with vendors or Telkom. By doing this the SAOUG can perhaps become a much more influential society to even better fulfil its aims and functions.

Roles of individual members of the SAOUG

As members of the SAOUG individual members undoubtedly contribute to the informatisation of society. In this brief discussion attention will be paid only to their contribution to informatisation of society in their private capacities as ordinary members of society.

\section{a) Responsible information citizens}

Members of the SAOUG in their capacities as ordinary members should set an example as responsible and respectable users of information. They could demonstrate to the general public their ability to identify their own user needs, on how to use information for personal development and in their daily work, to be champions of the free flow of information, etc. As information professionals they should, for instance, act as examples of informatised individuals and act as role models for the youth of South Africa.

\section{b) Personal development}

Every individual member of the SAOUG should always strive to improve his or her abilities to act as agents of informatisation in society. This implies that they must accept responsibility for their own professional development by attending conferences, seminars, by reading professional literature and newspapers and to be curious about developments not only in the field of online information retrieval but in related fields such as sociology, psychology, linguistics, politics, etc. An information professional in an informatised society should not suffer from tunnel vision or being guilty of only sticking to attitudes that were acceptable in the print era.

Individual members of the SAOUG could also enrol for formal qualifications in Information Science, Communication, Archival Studies, Publishing, Societal Informatisation, etc. The University of South Africa (Unisa?, for instance, is offering such a degree, namely, a BA (Culture and Arts) with specialisation in Societal Informatisation. The purpose of the degree is "to deliver graduates, able and competent, to work as knowledge configurers in all possible fields or contexts related to knowledge application and informatisation in order to extensively promote knowledge usage in local and international communities, in all sectors of societies, with a view to the comprehensive development and growth of all our people." (Unisa 2003:10I).

The University of Pretoria offers degrees in Publishing, Information Science, Web Design. etc. Other universities such as the Universities of Cape Town, KwaZulu-Natal, and Stellenbosch all offer qualifications that can be used by individual members of the SAOUG for personal development and growth.

As professionals, individual members of the SAOUG should also participate in continuous professional education. The SAOUG can offer these programmes or they can approach educational providers to develop short courses in societal informatisation for instance.

\section{c) Research}

In their personal capacity individual SAOUG members should get involved in research projects on informatisation, the transfer of information, access to information, etc. Non Governmental Organisations (NGO's) can use the expertise of members of SAOUG to identify, design and conduct research into people's information needs, on how to promote the use of information or the protection of the rights to privacy of the citizens of the RSA. 


\section{d) Promote access to information}

In this regard SAOUG members could play a pivotal role in promoting the Promotion of Access to Information Act (PAIA) in their communities and in society by making people aware of their rights under this act. Access to other information sources available in the public domain and even in the private sector should form part of this activity.

In the professional literature much is being written on the disintermediation effect of IT, and that intermediaries will disappear in the information society. This is a debate that will not be entered into in this article. In their personal capacities many information professionals will be offered an opportunity to still act as information intermediaries to help people assess their information needs, to find the relevant information and to protect the informational rights of disadvantaged citizens. Members of the SAOUG should be known in their communities as information intermediaries and information specialists.

\section{e) Ethical conduct}

It is the responsibility of the SAOUG but also of its members to always act ethically in their daily work, as well as in their private lives. It is often stated that the growth in access to and need for information implies a related growth or increase in the ethical responsibilities and conduct of information professionals. Members of the SAOUG should be aware of the ethical dilemmas facing them such as unequal access to information, the moral and political issues of information, etc. (Dick 2002:63).

\section{Conclusion}

Informatisation of society as concept refers to the process whereby especially computers and telecommunications are used to provide access to information, to change production processes and indeed create a new kind of society, the networked, information, knowledge or informatised society. Preference in the article is given to the informatised society, as it does not imply a complete break with preceding eras such as the industrial or agricultural.

The South African Online User Group can, as a society, make a significant contribution to societal informatisation by, inter alia, through human resources development, promoting access to information and to sensitise society to the important role that information plays in contemporary societies.

Individual members of the SAOUG can make an equally valuable contribution to societal informatisation by acting as responsible information citizens, by promoting access to information and in their personal lives as examples of informatised individuals. They should realise that this may imply a new kind of information professional, i.e., as a helper, a kind of social worker for information, showing respect for indigenous knowledge systems, activists for the rights of society for access to information, as reconfigurers of knowledge and as evaluators of knowledge.

The SAOUG should become much more visible in the public eye and should be seen as information missionaries spreading the message that information is essential for the survival of humankind in all societies. This mind shift is essential if we want to survive as information professionals in an informatised society.

\section{References}

Castells, M. 1996. The information age: economy, society and culture: the rise of the network society. Oxford: Blackwell.

De Beer, CS. 1996. Informatization of society. Centre for Library and Information Service Department of Information Science. Pretoria: University of South Africa.

De Beer, CS. 1998. 'n Skets van die hedendaagse inligtinglandskap. Mousaion, 16(1):74-103.

De Beer, CS. 2002. The new knowledge dispensation. (Unpublished lecture given at the University of South Africa, June 6.)

De Mul, J. 1999. The informatization of the worldview. Information, Community and Society, Spring:69-94.

Dick, Al. 2002. The philosophy, politics and economics of information. Pretoria: Unisa Press.

Duff, AS. 2003. Four "e"pochs: the story of informatization. Library Review, 52(2):58-64.

English-Russian glossary on the information society. One hundred basic terms: Informatization. (200I). British Council in Russia and Institute of the Information Society - Russia. Available at: http://www.iis.ru/glossary/informatisation.en.html (Accessed 9/5/ 2003)

Extent of UK snooping revealed. 2003. Available at: http://news.bbc.co.uk/go//pr/fr///2/hi/technology/303085I.stm (Accessed on 21/5/2003)

Google. 2003. Available at: http://www.google.com. (Accessed on 9/5/2003)

Haywood, T. 1997. Praise the Net and pass the modem: revolutionaries and captives in the information society. Library Review, 46(7): 472-489. Available at $h t t p: / /$ taddeo.emeraldinsight.com $/ v l=78 / 2 / 15 / \mathrm{cl}=74 / \mathrm{nw}=1 / \mathrm{rps} / \mathrm{cw} / \ldots / \mathrm{p} 472 . h t m$ (Accessed on 9/ $5 / 2003)$

http://www.saoug.org.za (Accessed on 22/5/2003)

Kebbles se dagvaardings na DRD en andere gestuur. 2003. Sake-Beeld, 21 Mei:6.

Key concepts in communication and cultural studies. 1994. $2^{\text {nd }}$ ed. London: Routledge.

Kumon, S. 1999. How Japan fell behind in informatization. Available at: www.glocom.ac.jp/lib/kumon/99/informatization.html (Accessed on 9/5/2003)

Levy, P. 1997. Collective intelligence: mankind's emerging world in cyberspace. New York: Plenum Trade. 
Lim, E. 1999. Human resource development for the information society. Asian Libraries, 8(5): I43-16I.

Available at: $h t t p: / /$ taddeo.emeraldinsight.com $/ v l=78121 / 5 / c l=74 / \mathrm{nw}=1 / \mathrm{rps} / \mathrm{cw} / \ldots / \mathrm{p} / 43 . \mathrm{htm}$ (Accessed on 9/5/2003)

Lyon, D. 1988. The information society: issues and illusions. Cambridge: Polity.

Minc, A. 1987. The informatisation of society, in Evolution of an information society, edited by AE Cawkell. London: ASLIB: 134140.

Nora, S \& Minc, A. 198I. The computerizsation of society: a report to the President of France. Cambridge, Mass: The MIT Press.

Postman, N. 1990. Informing ourselves to death. Stuttgart: German Informatics Society.

Robbins, K \& Webster, F. 1999. Times of the technoculture: from the information society to the virtual life. London: Routledge.

Seufert, LM. 2004. Internet resources: Professional associations and user groups provide information and contacts. Technews, 3(4). Available at: http//:www.uwnyc.org/technews/v3_n4_a2.html (Accessed on:04/05/2004).

Suriya, M. 1998. The impact of informatisation on economic and human development: a cross-country analysis. Asian Libraries, 7(7): 152- 170. Available at: $h t t p: / / p i p p o . e m e r a l d i n s i g h t . c o m / v l=5627997 / \mathrm{cl}=28 / \mathrm{nw}=1 / \mathrm{rps} / \mathrm{cw} / \ldots / \mathrm{p} / 52 . \mathrm{htm}$ (Accessed on 9/5/ 2003)

Theron, JC 2003. Modern societies as knowledge societies: a South African perspective. Proceedings of the $8^{\text {th }}$ Biannual Conference of the International Society for the Study of European Ideas, 20-27 July 2002, Aberystwyth, Wales. Aberystwyth: The Society. (CD ROM).

UKOLUG - UK elnformation Group. 2004.Avaiable at: http://www.ukolug.org.uk/content/public/about/index.html (Accessed on 04/ 05/2004)

University of South Africa. 2003. Calendar, Part 2: Rules: Undergraduate Qualifications. Pretoria.

Welcome to the Orange Apple Computer Club of Orange County. 2004. Available at: http://www.oacc.org/second page/ usergroupss.html (Accessed on: 04/05/06).

Wersig, G. 1990. The changing role of information in an information society, in The information environment: a world view, studies in honour of Professor Al Mikhailov. North Holland: Elsevier: 185-198. 